\title{
EFL Pre-Service Teachers' Perception of Language Use for Medium of Instruction in English Classroom
}

\author{
Urip Sulistiyo, Eddy Haryanto, Retno Wulan \\ Faculty of Education and Teacher Training, Jambi University, Indonesia \\ Urip.sulistiyo@unja.ac.id
}

\begin{abstract}
The purpose of this research was to investigate the learners' perception toward teaching English using Bahasa or English in the classroom, learners' preference for language use as the medium of instruction in English classroom, what subjects that can be taught by using Bahasa. The participants were EFL pre-service teachers in the fourth semester at one university in Jambi Province, Sumatra, Indonesia. This research used purposive sampling with 57 participants. This research was mix methods by employing the questionnaire and focus group discussion (FGD) as the instruments. The data from the questionnaire were analyzed by using SPSS program while FGD's data were transcribed to collect the answer to support the statement from the questionnaire.The findings showed that preservice teachers were exciting to have English as the medium of instruction in their classroom. However, they also welcome their L1 (Bahasa Indonesia). In addition, they preferred having English to having Bahasa as the medium of instruction in their English classroom. Thus, the use of both their L1 and L2 should be balanced. Moreover, regarding what subjects that pre-service teachers need the use of English only in the classroom, they nominated Listening and Speaking subjects.
\end{abstract}

Key words: EFL student teachers, first language, foreign language

\section{INTRODUCTION}

People communicate with each other to build relationship by using language. There are many languages available in this world. Those languages have their own characteristic which makes them different from one to another, including English. English is seen as the lingua franca where it acts as the additional language to the speakers who speak it (Mauranen \& Ranta, 2009). According to Goodwyn and Branson (2005), language is a very essential tool for everyone in their society because it determines the individual. It then describes how important language is for people all over the world. Additionally, Thompson and Evans (2005) stated that "Language is the ability to understand and use a structured system of communication" (p. 1). Since there are many people need to learn English to keep up with others, Learning English has become a major activity among the students, they realize that English is very popular and becomes a global language. Crystal (2003) said that a language will get global status when it gives particular role and accepted in every country.

English and Bahasa are the languages used in English classroom teaching. Therefore, we cannot deny that they both are important, but what will happen to the students if they are taught mostly in English only? Or mostly in Bahasa? Of course that situation will impact the students, especially their
English ability. According to Swain (2008), it is a good idea to give the chance to the students to use most L2 in second language classroom to have good written and spoken input. In other word, students need to use English in order to practice themselves to have good proficiency in English classroom. Kreshen (1981 as cited in Purnama, 2014) and Cook (2008) stated that L2 will benefit the adult learners in learning process in the second language class to make them more active. Moreover, Kreshen (1981 as cited in Purnama, 2014) pointed out that the input hypothesis plays a crucial role in learning the second language; he then argued that the learners will be able to acquire the language only when they understand the message delivered from the teachers. One research conducted in Kenya and Uganda pointed out that parents have high expectations in using English for their children to understand the subject matter better than using of their mother tongue.

Moreover, the use of Bahasa in English teaching is also helpful, as long as it is not too dominant over English in the classroom. When the students are taught only in Bahasa, they have no capability to use English, and have no chance to master English. According to Christina and Georgiana (2012), there are some disadvantages when using L1 in L2 classroom. First, the overuse of L1 might become a habit for both teachers and learners in teaching and learning process. In University level, if the lecturers always rely on the use of L1, it will be possible the use of L1 become the habit in the classroom. When lecturers are speaking the L1, the students (pre-service teachers) will feel comfortable in joining the lectures. Apparently, the lecturers' language is the real model for the real communication happening in the second language classroom (Cook, 2008). Second, L1 may lead to misunderstanding when students try to get their target language. It happens because there are some words in target language that do not have the appropriate meaning in the first language and vice versa.

This study aimed to investigate pre-service teachers perception of language use for the medium of instruction in English classroom and to know what kind of subjects that can be delivered using Bahasa. Some researchers around the world such as Wong (2010), Al-Sharaeai (2012), and Snorradóttir (2014), have studied about learning foreign language and language using in teaching foreign language in the classroom. Although many researchers believe that teaching through English will give better result and improvement to the students, research on Indonesian students whose English as their foreign language need to be explored further. The 
purposes of this research were to reveal what students' perception toward teaching English using Bahasa or English in their English classroom is, their preference for language use in their English classroom is, and kind of subjects like listening, speaking, reading, writing, vocabulary and grammar can be taught by using Indonesian language.

\section{METHOD}

This study was mixed methods design with the questionnaire and focus group discussion (FGD) as the instruments. A total of 57 participants in the fourth semester from one of the universities in Jambi Province, Sumatra, Indonesia were taken. The participants were chosen because they are EFL learners who had passed their subject skills (listening, speaking, reading, and writing) also grammar and vocabulary in their previous semesters. Moreover, among the participants, $16(28.1 \%)$ participants were male, and 41 (71.9\%) were female.Data collection consisted of the survey questionnaire and the focus group discussion (FGD). The questionnaire was used to reveal the students' perception and their preference for language use as the medium of instruction in their English classroom. It also revealed about the kinds of subject could be taught through Bahasa Indonesia (Indonesian language). Meanwhile, FGD was conducted to support the data gathered through the survey questionnaire and to reveal the advantages in using both L1 and L2 in second language learning process. The questionnaire was contributed in March, 2016. FGD was conducted in the next morning within fourteen students in one classroom. It took about $40-45$ minutes. All of the participants did not receive any compensation for their participation in this research. However, we provided the cookies and drinking for those who joined in FGD.

The data was analyzed statistically by using SPSS program. The reliability of the questionnaire was .700. The data analysis used were frequency, percentage, mean, and level interpretation of mean from each item to get their perception and preference of language use as the medium in English classroom. Since there are some parts in the questionnaire, then we showed the result based on the parts determined for each item. We also compared the result for those who preferred to use Bahasa with those who preferred to use English.

\section{RESULT DISCUSSION 3.1 LEARNERS' PERCEPTION TOWARD ENGLISH USE IN ENGLISH CLASSROOM}

In Q1 (I like when my English teacher only uses English as the medium of instruction). From all 57 students, only 1 student $(1.8 \%)$ chose strongly disagree, 5 students $(8.8 \%)$ chose disagree, 12 students $(21.1 \%)$ chose tend to disagree, 19 students $(33.3 \%)$ chose tend to agree, 17 students (29.8\%) chose agree and 3 students $(5.3 \%)$ chose strongly agree. In Q5 (English teachers are good examples if they only use English in English class), there were 2 students (3.5\%) chose strongly disagree, 2 students $(3.5 \%)$ chose disagree, 5 students $(8.8 \%)$ chose tend to disagree, 15 students $(26.3 \%)$ chose tend to agree, 26 students $(45.6 \%)$ chose agree and 7 students $(12.3 \%)$ chose strongly agree. Finally, in Q7 (It is fun to listen to my friends speaking English in the class), there were no students $(0 \%)$ chose strongly disagree, 1 student (1.8\%) chose disagree, 1 student $(1.8 \%)$ chose tend to disagree, 10 students $(17.5 \%)$ chose tend to agree, 25 students (43.9\%) chose agree, and 20 students $(35.1 \%)$ chose strongly agree.

It was alsofound out through FGD that there were some students (S1, S3, S4, S6, S8, S9, S10, S12, and S14) stated that English as the medium of instruction in the classroom was good to improve their skill especially in speaking skills, but it was hard because some of students could catch the idea but some others could not understand about the material given by their teachers. Furthermore, they also could not learn fast when they were taught in English. Moreover, it was difficult for them to gain new words from their lectures. Yet, they liked when their lecturers spoke English in front of the classroom because it can improve their skills, and could add their vocabularies. Therefore, they seemed do not feel excited when English was used as the medium of instruction in their classroom and found it was hard and they could not enjoy their teaching - learning process in their English classroom.

Meanwhile, there were also some students (S2, S5, S7, S11, and S13) said that they were okay with English as the medium of instruction in the classroom. They were feeling comfortable in using English as the medium of instruction in their classroom. They could understand what their teacher explained to them although they were passive learners. They stated that English was very important for them. By using English in their English classroom, they were able to produce new words, they could be active learners, and they had high self-confidence to speak with their teachers and friends.

\subsection{LEARNERS' PERCEPTION TOWARD BAHASA USE IN ENGLISH CLASSROOM}

In Q2 (I like when my English teacher tend to use Bahasa as the medium of instruction), from all 57 students, only 2 students $(3.5 \%)$ chose strongly disagree, 6 students $(10.5 \%)$ chose disagree, 21 students $(36.8 \%)$ chose tend to disagree, 16 students $(28.1 \%)$ chose tend to agree, 10 students (17.5\%) chose agree and 2 students $(3.5 \%)$ chose strongly agree. Furthermore, in Q6 (English teachers are good to use Bahasa when they teach English), there were 2 students (3.5\%) chose strongly disagree, 13 students (22.8\%) chose disagree, 21 students $(36.8 \%)$ chose tend to disagree, 15 students $(26.3 \%)$ chose tend to agree, 5 students $(8.8 \%)$ chose agree and only 1 student (1.8\%) chose strongly agree. Finally, in Q8 (I will not be upset if my friends also speak Bahasa in the class), there were only 1 student $(1.8 \%)$ chose strongly disagree, 7 students $(12.3 \%)$ chose disagree, 2 students $(3.5 \%)$ chose tend to disagree, 9 students $(15.8 \%)$ chose tend to agree, 29 students $(50.9 \%)$ chose agree, and 9 students $(15.8 \%)$ chose strongly agree.

There were seven students (S1, S2, S3, S10, S11, $\mathrm{S} 12$, and S13) had similar opinions that Bahasa use as the medium of instruction in their English classroom was good 
because it could help them understand more about the material given by their lecturers in the classroom. Furthermore, they also could learn more effectively compared when they were taught only in English. In other word, Bahasa Indonesia (Indonesian language) makes them learn and understand the material given effectively.

\subsection{LEARNERS' PREFERENCE FOR ENGLISH USE AS THE MEDIUM OF INSTRUCTION IN THE CLASSROOM}

Q3 (English-only using in the classroom can improve my English standard), from all 57 students, no one chose strongly disagree $(0 \%)$, only 1 student $(1.8 \%)$ chose disagree, 8 students $(14.0 \%)$ chose tend to disagree, 4 students $(7.0 \%)$ chose tend to agree, 28 students $(49.1 \%)$ chose agree and 16 students $(28.1 \%)$ chose strongly agree. Furthermore, in Q9 (Given the choice, i prefer using English-only in English classes instead of mixing it with Bahasa), there were only 1 student $(1.8 \%)$ chose strongly disagree, 5 students $(8.8 \%)$ chose disagree, 8 students $(14.0 \%)$ chose tend to disagree, 14 students $(24.6 \%)$ chose tend to agree, 23 students $(40.4 \%)$ chose agree and 6 students (10.5\%) chose strongly agree. Finally, in Q11 (If my English teacher uses English to teach English, I will be exciting), there were no students chose strongly disagree and disagree $(0 \%)$, but 7 students $(12.3 \%)$ chose tend to disagree, 17 students $(29.8 \%)$ chose tend to agree, 24 students (42.1\%) chose agree, and 9 students $(15.8 \%)$ chose strongly agree.

\subsection{LEARNERS' PREFERENCE FOR BAHASA USE AS THE MEDIUM OF INSTRUCTION IN THE CLASSROOM \\ Q4 (The use of Bahasacan make me master English} well), from all 57 students, 8 students (14.0\%) chose strongly disagree, 10 students $(17.5 \%)$ chose disagree, 12 students $(21.1 \%)$ chose tend to disagree, tend to agree, and agree and 3 students $(5.3 \%)$ chose strongly agree. Furthermore, in Q10 (Given the choice, i prefer using Bahasa in English classes instead of English -only), there were only 2 students (3.5\%) chose strongly disagree, 11 students $(19.3 \%)$ chose disagree, 26 students $(45.6 \%)$ chose tend to disagree, 15 students (26.3\%) chose tend to agree, 2 students $(3.5 \%)$ chose agree and 1 student $(1.8 \%)$ chose strongly agree. Finally, in Q12 (If my English teacher uses Bahasa to teach English, I will be exiting), there were 2 students (3.5\%) chose both strongly disagree and disagree, 27 students (47.4\%) chose tend to disagree, 18 students $(31.6 \%)$ chose tend to agree, 5 students $(8.8 \%)$ chose agree, and 3 students $(5.3 \%)$ chose strongly agree. While from the FGD, the learners that had been asked had the same answer, they preferred to have English in their classroom. Even though Bahasa was important, and it could help them more understand the material, but English was much better since they were in English study program. Tsukamoto (2011) conducted a study in Japan. He then revealed that the EFL Japanese students also prefer to have English (L2) than their L1 (Japan) in their classroom since the students want to practice and develop their speaking and listening skill. Therefore, they very welcome English in their classroom.
The students tend to agree on the use of Bahasa when the lecturers teach Grammar with mean score gotten was (3.63), Vocabulary (3.28), Writing (3.24), and Reading (3.14) in their classroom. Meanwhile, they tend to disagree when the lecturers teach listening (2.85) and speaking (2.03) through Bahasa Indonesia. In other words, for two subject skills such as listening and speaking, the lecturers should teach them in English. Through FGD, some of the students stated that writing and reading should be taught through Bahasa but most of them chose Grammar and Vocabulary that can be taught through Bahasa. Ur (1991) stated that the things needs to be taught in vocabulary are aspects of meaning: denotations, connotation, and appropriateness. Additionally, according to Richards and Renandya (2002), students may master the rules, pass the examination, creates the illusion they know the language but when it comes to the real words, they cannot use the grammar well in communicating because they lack of vocabulary and fluency.

\subsection{ADVANTAGES OF USING ENGLISH IN THE CLASS}

Some students (S1, S2 S4, S5, S6, S8, S9, S10, S11, $\mathrm{S} 12$, and S13) had similar opinions about the advantages of English use as the medium of instruction in their English classroom. They stated that English could help them improve their skill both in receptive and productive skills. It also could improve their vocabularies, how to construct new sentences when they were leaning the grammar and developed their ability to make them better in the future. English also could expand their knowledge and their experiences. By having English as the medium of instruction in their English classroom, they would be able to speak that language and made it as their habit. Furthermore, they would understand what their lecturers explain to them in teaching-learning process. They also stated that the aim of English study program students was to be able to master English. In other word, when they are taught by using English in their English classroom, they will be able to master it, and have English as their habit. Meanwhile, there were two students (S3 and S14) stated that English had other benefit for them. English helped them to communicate with people surround them, such as their friends, parents, sisters, and so on. As cook (2008) stated that "teachers' language can be the prime model for the communicative use of the second language" (p. 181). In other word, English is useful for them to communicate with other people in this global era.

\subsection{THE ADVANTAGES OF USING BAHASA IN THE CLASS}

Although the students believe that there were so many advantages in using English, they also could not deny that Bahasa Indonesia is still important in their English classroom for teaching "hard" lesson or when the students are difficult to get the whole point of the material explained by the lecturers in the classroom. This finding proves that the learners are best taught by using their L2 (English) Krashen (1981 as cited in Purnama, 2014) and Cook (2008). However, when they found difficulty about the lessons explained by 
their lecturers in the classroom, Bahasa can be an alternative for them to make the lecturers' explaining easier and more clear. If the EFL students taught in Bahasa Indonesia, it will help them understand certain hard lessons. The use of L1 benefits them in comprehending some lessons, clearing the material given by the students, adding their vocabulary and giving them chance to master their L2 by using their L1. When they can understand the material given, it will be easy for them to get the objective of their self in the classroom; they can learn fast and well.

\section{CONCLUSION}

The purpose of this research was to reveal what students' perception toward teaching English using Bahasa or English in their English classroom and their preference for language use in their English classroom, as well as what subjects such as listening, speaking, reading, writing, vocabulary and grammar can be taught by using Indonesian language. The result indicated that the learners were happy when they were taught by using English and they welcome Bahasa Indonesia to make them get the exactly point of difficult explanation given by their lecturers in the classroom.In the light of the result, the EFL Learners found it is hard to have English as the medium of instruction in their English classroom. However, it is very good for them taught in English by the lecturers since they are English students and it will help them master English also make English as their habits.

This study recommends that English lecturers should take into account for pre- service teachers' need about the predominant language used in their English classroom. They should also attempt to have English in the classroom when they teach English, especially in the higher semester because the students have high expectation when they enter English study program that is to master English well. Although English is very important, lecturers should also see the situation when they students seem hard to get the point of what they have explained, they should use Bahasa only to emphasize the meaning of material they explained to the learners. Additionally, when the lecturers explain about the meaning of difficult vocabulary, or the rule in making a good sentence for communication, they should use Bahasa Indonesia only to emphasize the parts that the students have not understood yet.

\section{REFERENCES}

Al-Sharaeai, W. (2014).Students' perspectives on the use of L1 in English classrooms. Graduate thesis and dissertation. Lowa State University.

Christina \& Georgiana. (2012). Overusing mother tongue in English language teaching. International journal of communication research, 2(3), $212-218$.

Cook, V. (2008). Second language learning and language teaching $\left(4^{\text {th }}\right.$ ed.). London: Hodder Education.

Crystal, D. (2003). English as a global language.New York: Cambridge university.
Goodwyn, A., \& Branson, J. (2005).Teaching English a handbook for primary and secondary school teachers. London: Routledge.

Mauranen, A., \&Ranta, E. (2009).English as a lingua franca: Studies and findings. New York: Cambridge Scholars Publishing.

Purnama, D. (2014). Indonesian students who study English through two languages (Indonesian and English): A Case Study. Skripsi.Jambi University

Richards, J. C., \& Renandya, W. A. (2002).Methodology in language teaching: An anthology of current practice. New York: Cambridge University Press.

Snorradóttir, B. A. (2014).Language use in the English classroom:The role of students' first language in grades 9 and 10 in English classrooms in Iceland. B.Ed. Thesis. University of Iceland.

Swain, M. (2008). Theoutput hypothesis: Its history and its future.Foreign language teaching and research, 40(1), $45-50$.

Thompson, G., \& Evans, H. (2005).Thinking it through linking language skills, thinking skills and drama.Great Britain: David Fulton Publishers.

Tsukamoto, M. (2011).Students' perception of teachers' language use in an EFL classroom.(10), 143 - 154. Retrieved March 7, 2016, from http://irlib.wilmina.ac.jp/dspace/bitstream/10775/2438/1/d2011_ 08.pdf.

Ur, p. (1991).A course in language teaching.UK: Cambridge University Press.

Wong, R. (2010). The effectiveness of using English as the sole medium of instruction in English classes: Students responses and improved English proficiency. PortaLinguarium 13 (1697-7467), 119 - 130. 